\title{
Electrophysiological properties of anion exchangers in the luminal membrane of guinea pig pancreatic duct cells
}

\author{
N. Andharia ${ }^{1} \cdot$ M. Hayashi ${ }^{1}$ (D) H. Matsuda ${ }^{1}$
}

Received: 19 October 2017 / Revised: 10 January 2018 / Accepted: 23 January 2018 / Published online: 4 February 2018

(C) The Author(s) 2018. This article is an open access publication

\begin{abstract}
The pancreatic duct epithelium secretes the $\mathrm{HCO}_{3}{ }^{-}$-rich pancreatic juice. The $\mathrm{HCO}_{3}{ }^{-}$transport across the luminal membrane has been proposed to be mediated by SLC26 $\mathrm{A} \mathrm{Cl}^{-}-\mathrm{HCO}_{3}^{-}$exchangers. To examine the electrophysiological properties of $\mathrm{Cl}^{-}-$ $\mathrm{HCO}_{3}{ }^{-}$exchangers, we directly measured $\mathrm{HCO}_{3}{ }^{-}$conductance in the luminal membrane of the interlobular pancreatic duct cells from guinea pigs using an inside-out patch-clamp technique. Intracellular $\mathrm{HCO}_{3}{ }^{-}$increased the $\mathrm{HCO}_{3}{ }^{-}$conductance with a halfmaximal effective concentration value of approximately $30 \mathrm{mM}$. The selectivity sequence based on permeability ratios was $\mathrm{SCN}^{-}$ $(1.4)>\mathrm{Cl}^{-}(1.2)=$ gluconate $(1.1)=\mathrm{I}^{-}(1.1)=\mathrm{HCO}_{3}{ }^{-}(1.0)>$ methanesulfonate $(0.6)$. The sequence of the relative conductance was $\mathrm{HCO}_{3}^{-}(1.0)>\mathrm{SCN}^{-}(0.7)=\mathrm{I}^{-}(0.7)>\mathrm{Cl}^{-}(0.5)=$ gluconate $(0.4)>$ methanesulfonate $(0.2)$. The current dependent on intracellular $\mathrm{HCO}_{3}^{-}$was reduced by replacement of extracellular $\mathrm{Cl}^{-}$with gluconate or by $\mathrm{H}_{2} \mathrm{DIDS}$, an inhibitor of $\mathrm{Cl}^{-}-$ $\mathrm{HCO}_{3}{ }^{-}$exchangers. RT-PCR analysis revealed that the interlobular and main ducts expressed all SLC26A family members except Slc26a5 and Slc26a8. SLC26A1, SLC26A4, SLC26A6, and SLC26A10 were found to be localized to the luminal membrane of the guinea pig pancreatic duct by immunohistochemistry. These results demonstrate that these $\mathrm{SLC} 26 \mathrm{~A} \mathrm{Cl}^{-}-$ $\mathrm{HCO}_{3}{ }^{-}$exchangers may mediate the electrogenic $\mathrm{HCO}_{3}{ }^{-}$transport through the luminal membrane and may be involved in pancreatic secretion in guinea pig ducts.
\end{abstract}

Keywords Bicarbonate $\cdot$ Duct $\cdot$ Exchanger $\cdot$ Pancreas $\cdot$ Patch-clamp $\cdot$ SLC26

\section{Introduction}

The pancreas plays a pivotal role in digestion. Pancreatic acini secrete digestive enzyme-rich neutral fluid that is not dependent on the presence of the $\mathrm{CO}_{2} / \mathrm{HCO}_{3}{ }^{-}$-buffer system. However, ducts secrete a $\mathrm{HCO}_{3}{ }^{-}$-rich fluid, which is dependent on the presence of $\mathrm{CO}_{2} / \mathrm{HCO}_{3}{ }^{-}$-buffer, and that neutralizes acid chyme in the duodenum [32]. The generally accepted model for $\mathrm{HCO}_{3}{ }^{-}$transport involves $\mathrm{Cl}^{-}-\mathrm{HCO}_{3}{ }^{-}$exchangers that operate in parallel with cAMP-activated $\mathrm{Cl}^{-}$channels [cystic fibrosis transmembrane conductance regulator (CFTR)] and $\mathrm{Ca}^{2+}$-activated $\mathrm{Cl}^{-}$channels, such as TMEM16A/ANO1, on the luminal membranes of duct cells $[42,49]$. TMEM16A/ANO1 is also found specifically in the

M. Hayashi

hayashmi@hirakata.kmu.ac.jp

1 Department of Physiology, Kansai Medical University, 2-5-1 Shinmachi, Hirakata 573-1010, Japan apical membranes of the acinar cells and is the critical channel for the control of acinar fluid secretion [33]. In addition, $\mathrm{H}^{+}$ $\mathrm{K}^{+}$pumps and $\mathrm{K}^{+}$channels are expressed on the luminal membrane of pancreatic ducts $[11,28,45] . \mathrm{K}^{+}$channels are important for setting the resting membrane potential and for providing the driving force for anion transport, and may provide the transport partners for $\mathrm{H}^{+}-\mathrm{K}^{+}$pumps [10].

Electrophysiological studies have found a luminal $\mathrm{Cl}^{-}$conductance in rat pancreatic ducts $[6,27]$. Single-channel recordings revealed small-conductance $\mathrm{Cl}^{-}$channels on the luminal membrane of duct cells, which were identified as CFTR $\mathrm{Cl}^{-}$channels $[6,7]$. The $\mathrm{HCO}_{3}{ }^{-} / \mathrm{Cl}^{-}$permeability ratios of CFTR $\mathrm{Cl}^{-}$channels have been reported as 0.1 to $0.4[7,29]$ and demonstrated to be increased to 1.0 by reducing the intracellular $\mathrm{Cl}^{-}$concentration in pancreatic duct cells [31]. Measurement of intracellular $\mathrm{pH}$ and membrane potential of guinea pig duct cells suggested that $\mathrm{CFTR} \mathrm{Cl}^{-}$channels provide a significant pathway for $\mathrm{HCO}_{3}{ }^{-}$secretion [17].

Another pathway for $\mathrm{HCO}_{3}{ }^{-}$secretion across the luminal membrane is the $\mathrm{Cl}^{-}-\mathrm{HCO}_{3}{ }^{-}$exchanger, which has been identified as solute carrier family 26 member A6 (SLC26A6) [16, 
20, 48]. SLC26A6 has been found to be electrogenic with a $1 \mathrm{Cl}^{-} / 2 \mathrm{HCO}_{3}{ }^{-}$exchange stoichiometry in Xenopus oocytes and HEK 293 cells $[19,38]$. Consistently with this, deletion of Slc26a6 altered the overall stoichiometry of apical $\mathrm{Cl}^{-}-$ $\mathrm{HCO}_{3}{ }^{-}$exchange in native mouse interlobular ducts, suggesting the upregulation of $\mathrm{a} \mathrm{Cl}^{-}-\mathrm{HCO}_{3}{ }^{-}$exchanger with different stoichiometry [41]. Previous studies have demonstrated a functional coupling between $\mathrm{CFTR} \mathrm{Cl}^{-}$channels and $\mathrm{Cl}^{-}-$ $\mathrm{HCO}_{3}{ }^{-}$exchange activity in isolated pancreatic interlobular ducts $[15,43]$. Furthermore, a computational model suggested that the $\mathrm{HCO}_{3}{ }^{-} / \mathrm{Cl}^{-}$permeability ratio of apical $\mathrm{Cl}^{-}$channels of 0.4 was able to support $\mathrm{HCO}_{3}{ }^{-}$secretion [50]. However, few studies have examined the electrophysiological properties and regulation of $\mathrm{HCO}_{3}{ }^{-}$conductance across the luminal membrane of native pancreatic duct cells.

The aim of the present study was to identify $\mathrm{HCO}_{3}{ }^{-}$conductance that is important for pancreatic secretion. For this purpose, we directly measured $\mathrm{HCO}_{3}{ }^{-}$currents through the luminal membrane of guinea pig pancreatic duct cells using the patch-clamp method in the inside-out configuration. We demonstrated that the inward conductance is dependent on intracellular $\mathrm{HCO}_{3}{ }^{-}$and extracellular $\mathrm{Cl}^{-}$, and is blocked by $\mathrm{H}_{2}$ DIDS, an inhibitor of anion transporters, and thus conclude that such inward conductance is carried out via anion exchangers on the luminal membrane. Furthermore, we report the expression and localization of the SLC26A family in the interlobular and main pancreatic duct using molecular biological and immunohistochemical analyses.

\section{Methods}

\section{Preparation of pancreatic duct cells from guinea pigs}

Female Hartley guinea pigs (240-450 g, $n=35)$ were sacrificed by carbon dioxide stunning in accordance with protocols approved by the Animal Experimentation Committee, Kansai Medical University. Pancreatic ducts were isolated by enzymatic digestion and microdissection from the pancreas as previously described [12]. The pancreas was removed, and digested with collagenase (Type IV, $124 \mathrm{U} / \mathrm{ml}$; Worthington) and trypsin inhibitor $(0.01 \%$; Sigma $)$ in Tyrode solution at $37{ }^{\circ} \mathrm{C}$ for $1 \mathrm{~h}$ with vigorous shaking. Tyrode solution contained the following (in $\mathrm{mM}$ ): $140 \mathrm{NaCl}, 0.33 \mathrm{NaH}_{2} \mathrm{PO}_{4}$, $5.4 \mathrm{KCl}, 1.8 \mathrm{CaCl}_{2}, 0.5 \mathrm{MgCl}_{2}, 5 \mathrm{HEPES}$, and 5.5 D-glucose; $\mathrm{pH}$ was adjusted to 7.4 with $\mathrm{NaOH}$. Interlobular and intralobular ducts (outside diameter of 30-60 $\mu \mathrm{m}$ ) were microdissected under a stereomicroscope. The ducts were washed in Tyrode solution and then placed on coverslips pretreated with Cell-Tak (BD Biosciences). In order to allow patch-clamp access to the luminal membranes of the lining of epithelial cells, the ducts were split open by patch pipettes.

\section{Patch-clamp recording}

Standard patch-clamp techniques were used. Patch pipettes, pulled from capillaries of hard borosilicate glass (G-1.5; Narishige), had a resistance of 5-7 M $\Omega$ when filled with a standard $N$-methyl-D-glucamine (NMDG)$\mathrm{Cl}$ solution. The standard NMDG-Cl solution contained the following (in $\mathrm{mM}$ ): $130 \mathrm{NMDG}, 130 \mathrm{HCl}, 5 \mathrm{EGTA}$, and 10 HEPES; pH was adjusted to 7.4 with NMDG. The stripped duct was bathed in a standard bicarbonate solution consisting of the following (in $\mathrm{mM}$ ): $115 \mathrm{NaCl}, 5$ $\mathrm{KCl}, 1 \mathrm{CaCl}_{2}, 1 \mathrm{MgCl}_{2}, 25 \mathrm{NaHCO}_{3}, 10 \mathrm{HEPES}$ ( $\mathrm{pH} 7.4$, adjusted with $\mathrm{NaOH}$ ), and 5.5 D-glucose. The standard bicarbonate solution was equilibrated with $5 \%$ $\mathrm{CO}_{2}$ in $\mathrm{O}_{2}$. The membrane potential was corrected for the liquid junction potential at the tip of the patch pipette in the bathing solution, and for that at the tip of the indifferent reference electrode filled with Tyrode solution and placed in the bath. Experiments were conducted at 23-30 ${ }^{\circ} \mathrm{C}$. After the inside-out configuration was established, the solution in the perfusion chamber was switched to control bicarbonate solution. The control bicarbonate solution contained the following (in $\mathrm{mM}$ ): 130 $\mathrm{KHCO}_{3}, 5$ EGTA, and 10 HEPES; pH was 7.8-8.0 after adding bicarbonate. A standard chloride solution contained the following (in $\mathrm{mM}$ ): $130 \mathrm{KCl}, 5 \mathrm{EGTA}$, and 10 HEPES; $\mathrm{pH}$ was adjusted to 7.8 with $\mathrm{KOH}$. To record the $\mathrm{HCO}_{3}{ }^{-}$selective conductance, the control bicarbonate solution was mixed with the standard chloride solution to make different concentrations $(0,16,33,65$, and $130 \mathrm{mM}$ ) of $\mathrm{HCO}_{3}{ }^{-}$around $\mathrm{pH}$ 7.8-8.0. To test the anion selectivity, $\mathrm{KHCO}_{3}$ in the control bicarbonate solution was replaced with anions such as $\mathrm{KCl}, \mathrm{K}$-gluconate, $\mathrm{K}$-methanesulfonate, K-thiocyanate, or $\mathrm{KI}$ at $\mathrm{pH}$ 7.8. The concentration of free $\mathrm{Ca}^{2+}$ was calculated using the MaxChelator computer program. 4,4'-Diisothiocyano2,2'-dihydrostilbenedisulfonic acid disodium salt ( $\mathrm{H}_{2} \mathrm{DIDS}$; Toronto Research Chemicals) was directly dissolved at $0.5 \mathrm{mM}$ in control bicarbonate solution. 4-[[4Oxo-2-thioxo-3-[3-trifluoromethyl)phenyl]-5thiazolidinylidene]methyl]benzoic acid (CFTRinh-172; Santa Cruz Biotechnology) and 2-methyl8-(phenylmethoxy)imidazo[1,2-a]pyridine-3-acetonitrile (Sch28080; Santa Cruz Biotechnology) were dissolved in DMSO at a 1000-fold concentration for application. The current was recorded in the inside-out configuration using the EPC 800 patch-clamp amplifier (HEKA). The amplifier was driven by Clampex 9 (Axon) in order to allow the delivery of a voltage-ramp protocol with concomitant digitization of the current. The membrane potential was generally held at $0 \mathrm{mV}$, and the command voltage was varied from -80 to $+80 \mathrm{mV}$ over a duration of $800 \mathrm{~ms}$ every $10 \mathrm{~s}$. 


\section{RT-PCR analysis}

RNA was extracted from the interlobular (outside diameter of $50-150 \mu \mathrm{m}$ ) and main ducts (outside diameter of around $500 \mu \mathrm{m}$ ) from three independent guinea pigs using the RNeasy Plus Micro kit with DNase I (Qiagen). RT-PCR analysis was performed using the OneStep RT-PCR kit (Qiagen) with primers designed to recognize different types of transporters (Table 1). For the negative control of reverse transcription, we used Taq DNA Polymerase (Promega). The amplification parameters used were as follows: 1 cycle at $50^{\circ} \mathrm{C}$ for $30 \mathrm{~min}$ and 1 cycle at $95^{\circ} \mathrm{C}$ for $15 \mathrm{~min}$, followed by 40 cycles at $94{ }^{\circ} \mathrm{C}$ for $30 \mathrm{~s}, 57^{\circ} \mathrm{C}$ for $30 \mathrm{~s}, 72^{\circ} \mathrm{C}$ for $30 \mathrm{~s}$, and 1 cycle at $72{ }^{\circ} \mathrm{C}$ for $10 \mathrm{~min}$. The transcripts were subsequently verified by agarose gel electrophoresis.

\section{Immunolocalization}

Immunolocalization was performed on the guinea pig pancreas. The pancreas was obtained from female Hartley guinea pigs $(n=3)$ in accordance with protocols approved by the Animal Experimentation Committee, Kansai Medical University. The guinea pigs were anesthetized with isoflurane and a mixture of medetomidine $(0.5 \mathrm{mg} / \mathrm{kg}$ body weight), midazolam (5.0 $\mathrm{mg} / \mathrm{kg} \mathrm{b.w.),} \mathrm{and} \mathrm{butorphanol}$ $(2.5 \mathrm{mg} / \mathrm{kg}$ b.w.), and perfused transcardially with $4 \%$ paraformaldehyde. The pancreas was fixed with $4 \%$ paraformaldehyde in PBS for $24 \mathrm{~h}$, embedded in paraffin, and sectioned. Detailed methods for immunohistochemistry were described previously [12]. Briefly, autofluorescence was blocked by $0.1 \mathrm{M}$ Tris-glycine. Non-specific binding was blocked with $2 \%$ normal donkey serum in PBS. Preparations were subsequently incubated with primary antibodies for SLC26A1, SLC26A3, SLC26A4, SLC26A6, or SLC26A10 (Table 2), along with Ezrin (1:400 to 1:800, clone 3C12, MS-661; Lab Vision) and PECAM-1 (platelet endothelial cell adhesion molecule-1, 1:800, sc-1506; Santa Cruz Biotechnology) in immunoreaction enhancer solution (Can Get Signal immunostain; Toyobo) overnight at $4{ }^{\circ} \mathrm{C}$. Secondary antibodies conjugated to Alexa488 (SLC26A), Alexa568 (Ezrin), or Alexa647 (PECAM-1) (1:400; Molecular Probes) were added for $1 \mathrm{~h}$. For the negative control, the primary antibodies were pre-absorbed with corresponding antigens for SLC26A1 (APrEST81987; Atlas), SLC26A10 (APrEST84901), SLC26A4 (synthesized peptide; Eurofins Genomics), or SLC26A6 (synthesized peptide) for $30 \mathrm{~min}$ at room temperature. In the controls, the primary antibodies were omitted and scanning was performed using the same settings. Nuclei were stained with 4',6-diamidino-2-phenylindole (DAPI) at $1 \mu \mathrm{g} / \mathrm{ml}$. Fluorescence was observed with a confocal laser scanning microscope (LSM510 META; Carl Zeiss).
Table 1 Primer sets used for guinea pig pancreatic duct in RT-PCR analysis

\begin{tabular}{|c|c|c|}
\hline \multicolumn{2}{|c|}{ Gene (subunit) } & \multirow[t]{2}{*}{ Size $(b p)$} \\
\hline Cftr & & \\
\hline Forward: & 5'-GCTTAAAAGGACTATGGACACT -3' & 623 \\
\hline Reverse: & 5'-ACCTTCAGTGTTCAGCAGTCT -3' & \\
\hline \multicolumn{3}{|l|}{ Gapdh } \\
\hline Forward: & 5'-CAAAAGGGTCATCATCTCTGC -3' & 610 \\
\hline Reverse: & 5'-GCCGAACTCATTGTCATACCA -3' & \\
\hline \multicolumn{3}{|l|}{ CA2 } \\
\hline Forward: & 5'-AGCCTCTGCACCTTCACTATG -3' & 535 \\
\hline Reverse: & 5'-AACATCTGCTCACTGCTTACG -3' & \\
\hline \multicolumn{3}{|l|}{ Slc26a1 } \\
\hline Forward: & 5'-CTACTCTGTCCGTGCCAACCA -3' & 914 \\
\hline Reverse: & 5'-ACAGCTGCTCATCCTCCATTC -3' & \\
\hline \multicolumn{3}{|l|}{ Slc26a2 } \\
\hline Forward: & 5'-GGGGTTGGTTTTTCTATGTTTTG -3' & 554 \\
\hline Reverse: & 5'-AAACCCACCGCTTCATACACG -3' & \\
\hline \multicolumn{3}{|l|}{ Slc26a3 } \\
\hline Forward: & 5'-GTATGAGCCAGAAGGAGTGAA -3' & 459 \\
\hline Reverse: & 5'-TACACATCTACATTTATCCTTGC -3' & \\
\hline \multicolumn{3}{|l|}{ Slc26a4 } \\
\hline Forward: & 5'-AAACATCCCCACCACAGACAT -3' & 558 \\
\hline Reverse: & 5'-AAACCACATTGCTCCATCTGC -3' & \\
\hline \multicolumn{3}{|l|}{ Slc26a5 } \\
\hline Forward: & 5'-GTGACCTTGCTCTCGGGAAT -3' & 621 \\
\hline Reverse: & 5'-GAAGAGGGAGCCGATGGAAT-3' & \\
\hline \multicolumn{3}{|l|}{ Slc26a6 } \\
\hline Forward: & 5'-TCGGTCCTCAGCCACTTTGTA -3' & 544 \\
\hline Reverse: & 5'-ATGCTGCTTGGTGATAGATGC-3' & \\
\hline \multicolumn{3}{|l|}{ Slc26a7 } \\
\hline Forward: & 5'-CCCCAATGAACCTCCTGTCTG-3' & 713 \\
\hline Reverse: & 5'-AAGTAGGTGATTAGTGGCATTC-3' & \\
\hline \multicolumn{3}{|l|}{ Slc26a8 } \\
\hline Forward: & 5'-TCGGGGCTTGGTCGTCTTG-3' & 646 \\
\hline Reverse: & 5'-AGGTTGATAGATGGGCTGGTA-3' & \\
\hline \multicolumn{3}{|l|}{ Slc26a9 } \\
\hline Forward: & 5'-CTATCTGTACССТCTCCСТAA -3' & 721 \\
\hline Reverse: & 5'-AACGAGGGTATGGAAGGTAAC -3' & \\
\hline \multicolumn{3}{|l|}{ Slc26a10 } \\
\hline Forward: & 5'-ACTTTGCTGTGTGGATGGTCA-3' & 550 \\
\hline Reverse: & 5'-GCATCCTGGACACTCACAAAC-3' & \\
\hline \multicolumn{3}{|l|}{ Slc26a11 } \\
\hline Forward: & 5'-CAGGCAGCTTTGGGCGGAC-3' & 566 \\
\hline Reverse: & 5'-AGAGAAAACCAGGGAGACACC-3' & \\
\hline
\end{tabular}

\section{Western immunoblotting}

The pancreatic duct was dissected from three independent guinea pigs as described above. The ducts were washed with 
Table 2 Antibodies used for guinea pig pancreatic duct in immunohistochemistry (IHC) and western blotting (WB)

\begin{tabular}{|c|c|c|c|c|c|}
\hline \multirow[t]{2}{*}{ Protein (accession) } & \multirow[t]{2}{*}{ Antigen } & \multirow[t]{2}{*}{ Correlation with guinea pig } & \multicolumn{2}{|c|}{ Dilution } & \multirow[t]{2}{*}{ Catalogue number (manufacturer) } \\
\hline & & & $\mathrm{IHC}$ & WB & \\
\hline SLC26A1 (NP_071325) & $518-587$ & $77 \%$ & $1: 100$ & $1: 500$ & HPA041654 (Atlas) \\
\hline SLC26A3 (NP_000102) & $617-733$ & $85 \%$ & $1: 100$ & N/A & HPA036055 (Atlas) \\
\hline SLC26A4 (NP_000432) & $317-344$ & $93 \%$ & $1: 200$ & $1: 1000$ & bs-6787R (Bioss antibodies) \\
\hline SLC26A6 (NP_075062) & $438-484$ & $83 \%$ & $1: 200$ & $1: 1000$ & bs-20817R (Bioss antibodies) \\
\hline SLC26A10 (NP_597996) & $427-487$ & $75 \%$ & $1: 200$ & $1: 100$ & HPA044719 (Atlas) \\
\hline
\end{tabular}

cold PBS, treated with trichloroacetic acid (10\%) on ice for $30 \mathrm{~min}$, and then centrifuged. The pellet was solubilized in lysis buffer containing urea (9 M), Triton X-100 (2\%), dithiothreitol (1\%), and lithium dodecyl sulfate $(2 \%)$. The samples (30 $\mu \mathrm{g}$ /lane protein) were fractionated on SDS polyacrylamide gel $(7.5 \%)$, electroblotted to PVDF membranes (Merck Millipore), blocked with skim milk (1\%), and reacted with anti-SLC26A4, anti-SLC26A6, or anti-SLC26A10 antibodies (Table 2). For anti-SLC26A1, we used signal enhancer Hikari solution (Nacalai Tesque, Kyoto, Japan). The reaction was visualized with a secondary antibody labeled with alkaline phosphatase (Promega).

\section{Statistics}

Data are shown as means \pm SEM. A one-way analysis of variance (ANOVA) or Student's paired $t$ test was applied, and $P<0.05$ was considered significant. Data were analyzed in Igor or Microsoft Excel.

\section{Results}

\section{Bicarbonate conductance through the luminal membrane of the interlobular pancreatic duct cells}

We recorded macroscopic currents from excised inside-out patches from the luminal membrane of the interlobular pancreatic duct cells of guinea pigs under unstimulated conditions. Figure 1a shows the macroscopic current-voltage ( $I-$ $V)$ relationships in the presence of intracellular $\mathrm{HCO}_{3}{ }^{-}$at different concentrations $(0,16,33,65$, and $130 \mathrm{mM})$. As we used the standard NMDG-Cl pipette solution and the bathing solution containing $\mathrm{KHCO}_{3}$, the inward current was due to $\mathrm{HCO}_{3}{ }^{-}$ efflux through the luminal membrane. The inward conductance determined from the linear section of the $I-V$ relationships (from -80 to $-60 \mathrm{mV}$ ) increased with intracellular $\mathrm{HCO}_{3}{ }^{-}$concentration (Fig. 1a). The linear plot of conductance with the $\mathrm{HCO}_{3}{ }^{-}$concentration had a sigmoid relationship (Fig. 1b). The half-maximal effective concentration $\left(\mathrm{K}_{\mathrm{d}}\right)$ value for the effects of $\mathrm{HCO}_{3}{ }^{-}$and Hill coefficient were $31.5 \pm$
$5.1 \mathrm{mM}$ and $3.5 \pm 0.4(n=5)$, respectively. We also measured inward $\mathrm{HCO}_{3}{ }^{-}$currents in the bathing solution containing $130 \mathrm{mM} \mathrm{NaHCO}$. The inward conductance increased to $2.04 \pm 0.95 \mathrm{nS}$ in $\mathrm{NaHCO}_{3}$ from $0.34 \pm 0.08 \mathrm{nS}$ in $\mathrm{NaCl}$ (data not shown; $n=13$ ). Thus, there was a minor contribution of $\mathrm{K}^{+}$conductance under unstimulated conditions.

\section{Ion selectivity of the bicarbonate conductance}

Ion selectivity of the bicarbonate conductance was examined by replacing $130 \mathrm{mM} \mathrm{HCO}_{3}{ }^{-}$in the intracellular bathing solution with other monovalent anions. Figure 2 shows macroscopic $I-V$ relations recorded in the inside-out configuration with the standard NMDG-Cl pipette solution. In experiments where $\mathrm{HCO}_{3}{ }^{-}$in the bath was replaced with $\mathrm{Cl}^{-}$or gluconate $\left(\mathrm{glc}^{-}\right)$, the reversal potential did not change, but inward conductance significantly decreased from $1.30 \pm$ $0.09 \mathrm{nS}$ in $\mathrm{HCO}_{3}{ }^{-}$to $0.64 \pm 0.13 \mathrm{nS}$ in $\mathrm{Cl}^{-}$(Figs. 2a and $3 \mathrm{~b}$ (right); $n=5$ ) and from $1.69 \pm 0.08 \mathrm{nS}$ in $\mathrm{HCO}_{3}{ }^{-}$to $0.72 \pm 0.14 \mathrm{nS}$ in $\mathrm{glc}^{-}$(Fig. 2b; $n=5$ ). Replacement of $\mathrm{HCO}_{3}{ }^{-}$with methanesulfonate $\left(\mathrm{MES}^{-}\right)$shifted the reversal potential in a negative direction, indicating it was less
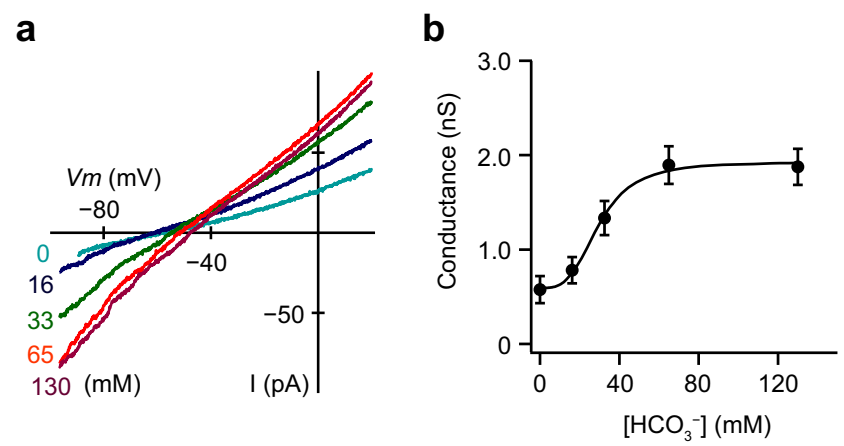

Fig. 1 Bicarbonate conductance through the luminal membrane of the interlobular pancreatic duct cells. a Macroscopic current-voltage $(I-V)$ relationships recorded from the luminal membrane of the pancreatic duct cells in the inside-out configuration with the standard NMDG-Cl pipette solution at different intracellular $\mathrm{HCO}_{3}{ }^{-}$concentrations. Inward conductance attributed to $\mathrm{HCO}_{3}{ }^{-}$efflux increased with $\mathrm{HCO}_{3}{ }^{-}$ concentration from 0 to $130 \mathrm{mM}$. b Linear plot of conductance by the $\mathrm{HCO}_{3}{ }^{-}$concentration. The solid line is the fit by the Hill equation with the half-maximal effective concentration of $31.5 \pm 5.1 \mathrm{mM}$ and a Hill coefficient of $3.5 \pm 0.4(n=5)$ 
permeable than $\mathrm{HCO}_{3}{ }^{-}$, and the inward conductance significantly decreased from $2.56 \pm 0.73 \mathrm{nS}$ in $\mathrm{HCO}_{3}{ }^{-}$to $0.73 \pm 0.36 \mathrm{nS}$ in $\mathrm{MES}^{-}$(Fig. 2c; $n=6$ ). Replacement of $\mathrm{HCO}_{3}{ }^{-}$with thiocyanate $\left(\mathrm{SCN}^{-}\right)$slightly shifted the reversal potential in a positive direction, but the inward conductance had little change (Fig. 2d; $n=6$ ). Finally, replacement of $\mathrm{HCO}_{3}{ }^{-}$with iodide $\left(\mathrm{I}^{-}\right)$did not cause a marked difference in the reversal potential or the inward conductance (data not shown; $n=6$ ). We calculated the permeability ratio $\left(P_{\mathrm{X}} / P_{\mathrm{HCO} 3}\right)$ from the shift in the reversal potential $\left(\Delta V_{\text {rev }}\right)$ when anion $\mathrm{X}$ is substituted for internal $\mathrm{HCO}_{3}{ }^{-}$[13]; that is, from:

$$
\Delta V_{\text {rev }}=(\mathrm{RT} / \mathrm{F}) \times \ln \left(P_{\mathrm{x}}\left[\mathrm{X}^{-}\right]_{\mathrm{i}} / P_{\mathrm{HCO}_{3}}\left[\mathrm{HCO}_{3}{ }^{-}\right]_{\mathrm{i}}\right),
$$

where $\mathrm{R}, \mathrm{T}$, and $\mathrm{F}$ have their conventional thermodynamic meanings. The sequence of the permeability ratios was $\mathrm{SCN}^{-}(1.41 \pm 0.15)>\mathrm{Cl}^{-}(1.18 \pm 0.14)=\mathrm{glc}^{-}$ $(1.07 \pm 0.03)=\mathrm{I}^{-}(1.06 \pm 0.06)=\mathrm{HCO}_{3}^{-}(1.00)>\mathrm{MES}^{-}$ $(0.65 \pm 0.11)(n=5-6)$. The sequence of the relative inward conductance determined from -80 to $-60 \mathrm{mV}$ was $\mathrm{HCO}_{3}{ }^{-}(1.00)>\mathrm{SCN}^{-}(0.69 \pm 0.10)=\mathrm{I}^{-}(0.66 \pm$ $0.09)>\mathrm{Cl}^{-}(0.48 \pm 0.08)=\mathrm{glc}^{-}(0.43 \pm 0.09)>\mathrm{MES}^{-}$ $(0.26 \pm 0.06)(n=5-6)$.

\section{Bicarbonate conductance is dependent on luminal $\mathrm{Cl}^{-}$}

To evaluate the activities of $\mathrm{Cl}^{-}-\mathrm{HCO}_{3}{ }^{-}$exchangers on the apical membrane of interlobular pancreatic ducts of the guinea pig, Ishiguro and colleagues replaced $\mathrm{Cl}^{-}$with gluconate in the lumen $[14,16,43]$. Similarly, we recorded macroscopic currents with extracellular solution containing $120 \mathrm{mM}$ gluconate and $10 \mathrm{mM} \mathrm{Cl}^{-}$. With the control intracellular solution, $E_{\text {rev }}$ was $-46.6 \pm 4.5 \mathrm{mV}$ with a standard NMDG-Cl pipette solution (Fig. 2a; $n=5$ ) and $-63.6 \pm$ $3.9 \mathrm{mV}$ with gluconate-rich pipette solution (Fig. 3a; $n=$ 5 ), demonstrating a significant difference (ANOVA). We also compared the inward $\mathrm{HCO}_{3}{ }^{-}$conductance with gluconate-rich and standard NMDG-Cl pipette solutions (Fig. 3b). The $\mathrm{HCO}_{3}{ }^{-}$conductance was significantly lower with the gluconate-rich pipette solution $(0.66 \pm 0.20 \mathrm{nS})$ than with standard NMDG-Cl pipette solutions (1.30 \pm $0.09 \mathrm{nS})(n=5$, ANOVA). Additionally, as described in the previous section, the inward conductance significantly decreased when $\mathrm{HCO}_{3}{ }^{-}$in the bath was replaced with $\mathrm{Cl}^{-}$, indicating that there was a minor contribution from $\mathrm{Cl}^{-}$dependent current (Fig. 3b, right). However, the inward conductance was not significantly different with gluconate-rich pipette solution (Fig. 3b, left). The results described so far indicate that both intracellular $\mathrm{HCO}_{3}{ }^{-}$and luminal $\mathrm{Cl}^{-}$are essential for the $\mathrm{HCO}_{3}{ }^{-}$conductance, and that the $\mathrm{HCO}_{3}{ }^{-}$conductance is carried out through $\mathrm{Cl}^{-}-$ $\mathrm{HCO}_{3}{ }^{-}$exchangers on the luminal membrane. a

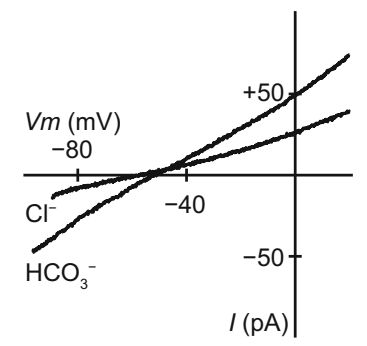

C

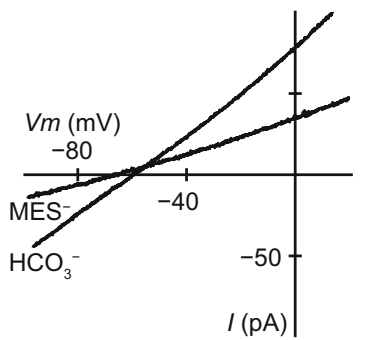

b

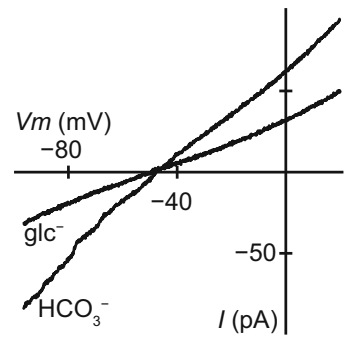

d

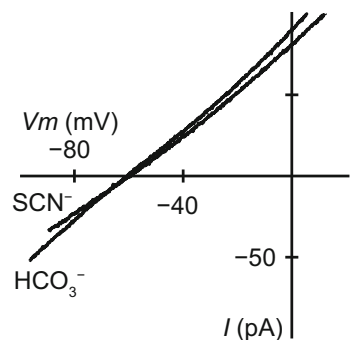

Fig. 2 Ion selectivity of bicarbonate conductance. Macroscopic $I-V$ relationships recorded from different inside-out patches. The intracellular $130 \mathrm{mM} \mathrm{HCO}_{3}^{-}$was substituted by equimolar chloride $\left(\mathrm{Cl}^{-}\right)$, gluconate $\left(\mathrm{glc}^{-}\right)$, methanesulfonate $\left(\mathrm{MES}^{-}\right)$, or thiocyanate $\left(\mathrm{SCN}^{-}\right)(n=5-6)$. The inward conductance decreased significantly when $\mathrm{HCO}_{3}^{-}$was substituted with $\mathrm{Cl}^{-}$, glc ${ }^{-}$, or MES

\section{Effects of the anion exchanger inhibitor $\mathrm{H}_{2}$ DIDS on bicarbonate conductance}

Previous studies reported that $\mathrm{Cl}^{-}-\mathrm{HCO}_{3}{ }^{-}$exchangers were inhibited by luminal $\mathrm{H}_{2}$ DIDS, a disulfonic stilbene [14, 43]. For experimental ease, we applied $\mathrm{H}_{2}$ DIDS $(0.5 \mathrm{mM})$ intracellularly while recording macroscopic currents from excised inside-out patches with the control bicarbonate internal and the standard NMDG-Cl pipette solutions. To exclude the possibility of the contamination of CFTR $\mathrm{Cl}^{-}$conductance, we included $20 \mu \mathrm{M}$ CFTRinh-172, an inhibitor of CFTR $\mathrm{Cl}^{-}$
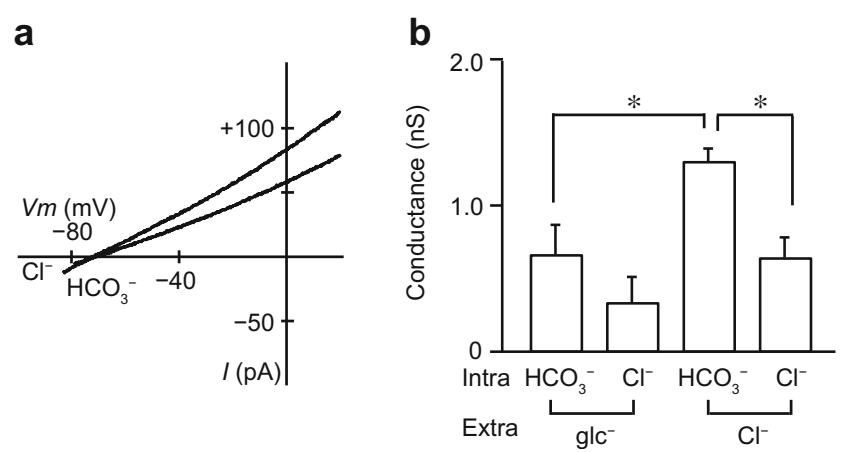

Fig. 3 Effects of substitution of extracellular $\mathrm{Cl}^{-}$with gluconate. a Macroscopic $I-V$ relationships recorded from the interlobular pancreatic duct cells with gluconate-rich extracellular and $130 \mathrm{mM} \mathrm{HCO}_{3}{ }^{-}$or $130 \mathrm{~m} \mathrm{M} \mathrm{Cl}^{-}$intracellular solutions. b The inward conductance attributed to efflux of $\mathrm{HCO}_{3}{ }^{-}$or $\mathrm{Cl}^{-}$with gluconate-rich and standard NMDG-Cl pipette solutions $(n=5, * P<0.05$, ANOVA). Intra and Extra, intracellular and extracellular, respectively 
channels, in the pipette solution. $\mathrm{H}_{2}$ DIDS applied intracellularly significantly decreased inward $\mathrm{HCO}_{3}{ }^{-}$conductance from $1.57 \pm 0.55$ to $0.86 \pm 0.37 \mathrm{nS}$ (Fig. $4 ; n=6$ ). We also tested $30 \mu \mathrm{M}$ Sch28080, a $\mathrm{H}^{+}-\mathrm{K}^{+}$-pump inhibitor, but did not observe any inhibitory effects on the inward $\mathrm{HCO}_{3}{ }^{-}$ conductance ( $n=4$; not shown). These results further support that the $\mathrm{HCO}_{3}{ }^{-}$conductance occurs through $\mathrm{Cl}^{-}-$ $\mathrm{HCO}_{3}{ }^{-}$exchangers.

\section{Regulation of bicarbonate conductance by intracellular ATP and CAMP}

In pancreatic duct cells, cAMP and $\mathrm{Ca}^{2+}$ signaling pathways play a role in fluid secretion. As CFTR $\mathrm{Cl}^{-}$channels were regulated by intracellular cAMP $[6,8,29]$ and ATP [40], we tested their effects on bicarbonate conductance. Application of intracellular $2 \mathrm{mM}$ ATP-Mg significantly increased the inward conductance from $1.51 \pm 0.59$ to $5.70 \pm 2.18 \mathrm{nS}$ (Fig. 5a, b; $n=13$ ). The addition of $1 \mathrm{mM}$ cAMP further increased the inward conductance to $14.8 \pm 5.57 \mathrm{nS}(n=4)$. cAMP also activated the marked outward conductance, which was attributed to $\mathrm{Cl}^{-}$influx, most likely through CFTR $\mathrm{Cl}^{-}$channels. Therefore, we tested the effects of intracellular ATP-Mg and cAMP with the pipette solution including CFTRinh-172 at $20 \mu \mathrm{M}$. In the presence of CFTRinh-172, application of intracellular $2 \mathrm{mM}$ ATP-Mg and $1 \mathrm{mM}$ cAMP had little effect on the conductance in either direction (Fig. 5c): the inward conductance was not significantly increased in the presence of ATP-Mg $(1.11 \pm 0.39 \mathrm{nS})$ or cAMP $(1.37 \pm 0.27 \mathrm{nS})$ as compared with the control $(0.98 \pm 0.29 \mathrm{nS})$ (Fig. $5 \mathrm{~d} ; n=11)$. These results indicate that intracellular ATP and cAMP may not directly regulate $\mathrm{Cl}^{-}-\mathrm{HCO}_{3}{ }^{-}$exchangers, but instead regulate CFTR $\mathrm{Cl}^{-}$channels on the luminal membrane of duct cells. Additionally, $1 \mu \mathrm{M}$ free $\mathrm{Ca}^{2+}$ added to the intracellular solution did not affect the inward $\mathrm{HCO}_{3}{ }^{-}$ conductance ( $n=3$; not shown), suggesting that intracellular $\mathrm{Ca}^{2+}$ does not regulate $\mathrm{Cl}^{-}-\mathrm{HCO}_{3}^{-}$exchangers directly.

\section{Pancreatic duct epithelia expressed a variety of SLC26A family members}

It is known that anion exchangers in pancreatic duct cells are members of the SLC26A family [26]. Two members of the family, SLC26A3 (DRA; downregulated in adenoma) [25] and SLC26A6 (PAT1; putative anion transporter-1) $[24,46]$, were reported to be expressed in the luminal membrane of pancreatic ducts and function as $\mathrm{Cl}^{-}-\mathrm{HCO}_{3}{ }^{-} \mathrm{ex}-$ changers $[9,19,20]$. Interlobular ducts from guinea pigs expressed mRNAs encoding Slc26a3 and Slc26a6 [43]. In the present study, we evaluated the expression of all members of the SLC26A family using RT-PCR analysis on isolated interlobular and main ducts. Figure 6a shows the
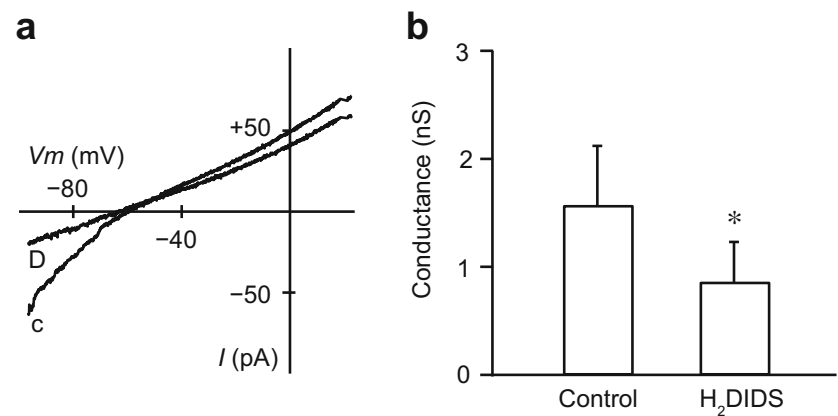

Fig. 4 Effects of $\mathrm{H}_{2}$ DIDS on bicarbonate conductance. a Macroscopic $I-$ $V$ relationships obtained in the absence or presence of $0.5 \mathrm{mM}$ intracellular $\mathrm{H}_{2}$ DIDS. c, control; D, $\mathrm{H}_{2}$ DIDS. CFTRinh- 172 at $20 \mu \mathrm{M}$ was added to the standard NMDG-Cl pipette solution. b $\mathrm{H}_{2}$ DIDS significantly decreased the average inward $\mathrm{HCO}_{3}{ }^{-}$conductance $(n=6$, $* P<0.05)$

isolated interlobular and main pancreatic ducts expressing CFTR and GAPDH. Then, we screened all 11 members of the SLC26A family from the interlobular ducts (Fig. 6b; $n=3$ animals) and main ducts (Fig. 6c; $n=3$ animals), along with GAPDH and a duct marker of carbonic anhydrase II (CA2). We also screened all primer sets from the total RNA of the kidney as a positive control (Fig. 6d). RT-PCR analysis revealed that the interlobular and main ducts expressed Slc26a1, Slc26a2, Slc26a3, Slc26a4, Slc26a6, Slc26a7, Slc26a9, Slc26a10, and Slc26a11.
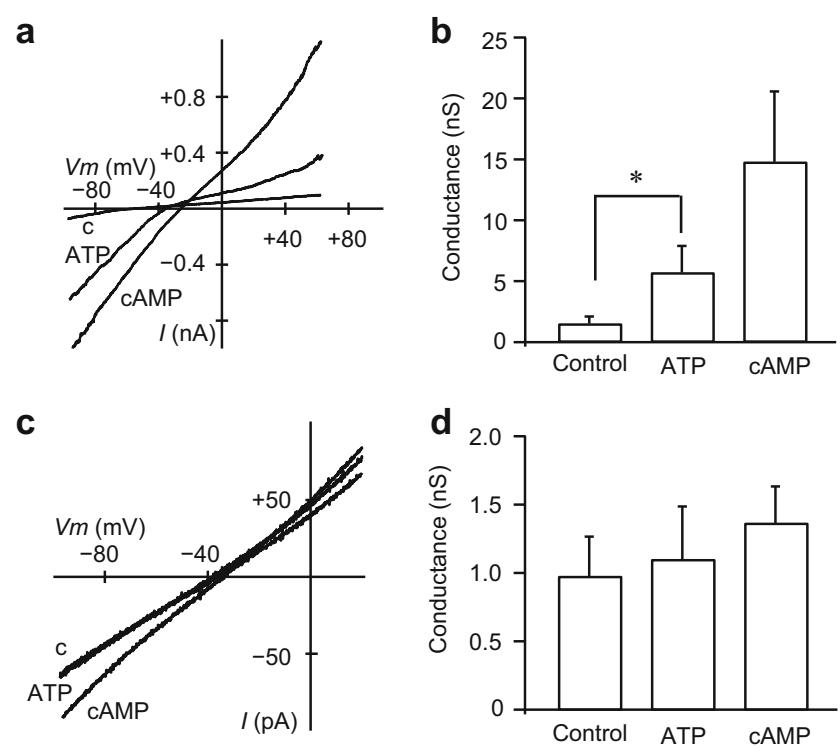

Fig. 5 Activation of bicarbonate conductance by intracellular ATP and cAMP. a Macroscopic $I-V$ relationships from the interlobular pancreatic duct cells with the control bicarbonate internal solution (c), and with addition of ATP alone, or ATP and cAMP. The standard NMDG-Cl pipette solution was used. b Averaged $\mathrm{HCO}_{3}{ }^{-}$conductance with the control, ATP alone $(n=13, * P<0.05)$, or ATP + cAMP $(n=4)$. c Macroscopic $I-V$ relationships obtained in the presence of extracellular CFTRinh-172 at $20 \mu \mathrm{M}$ along with the standard NMDG-Cl pipette solution. d Averaged $\mathrm{HCO}_{3}{ }^{-}$conductance with the control, ATP alone, or ATP + cAMP $(n=11)$ 
Fig. 6 RT-PCR analysis of the SLC26A family. Ethidium bromide-stained agarose gels show RT-PCR products generated from total RNA isolated from the interlobular (I) and main (M) pancreatic ducts. a Control experiment shows the amplification of Cftr (623 bp) and Gapdh (610 bp). No DNA fragment was amplified with the template without reverse transcription (RT). The primers for the RT-PCR analysis from the interlobular (b) and main (c) ducts gave the expected fragment length for Slc26a1-11 (Table 1). d Positive control obtained from the kidney. A representative gel for at least three independent experiments is shown. $\mathrm{M}$ in $\mathbf{a}-\mathbf{d}$ : molecular mass, $\mathrm{G}$ in $\mathbf{b}-\mathbf{d}$ : GAPDH, CA in $\mathbf{b}$ and $\mathbf{c}$ : carbonic anhydrase II

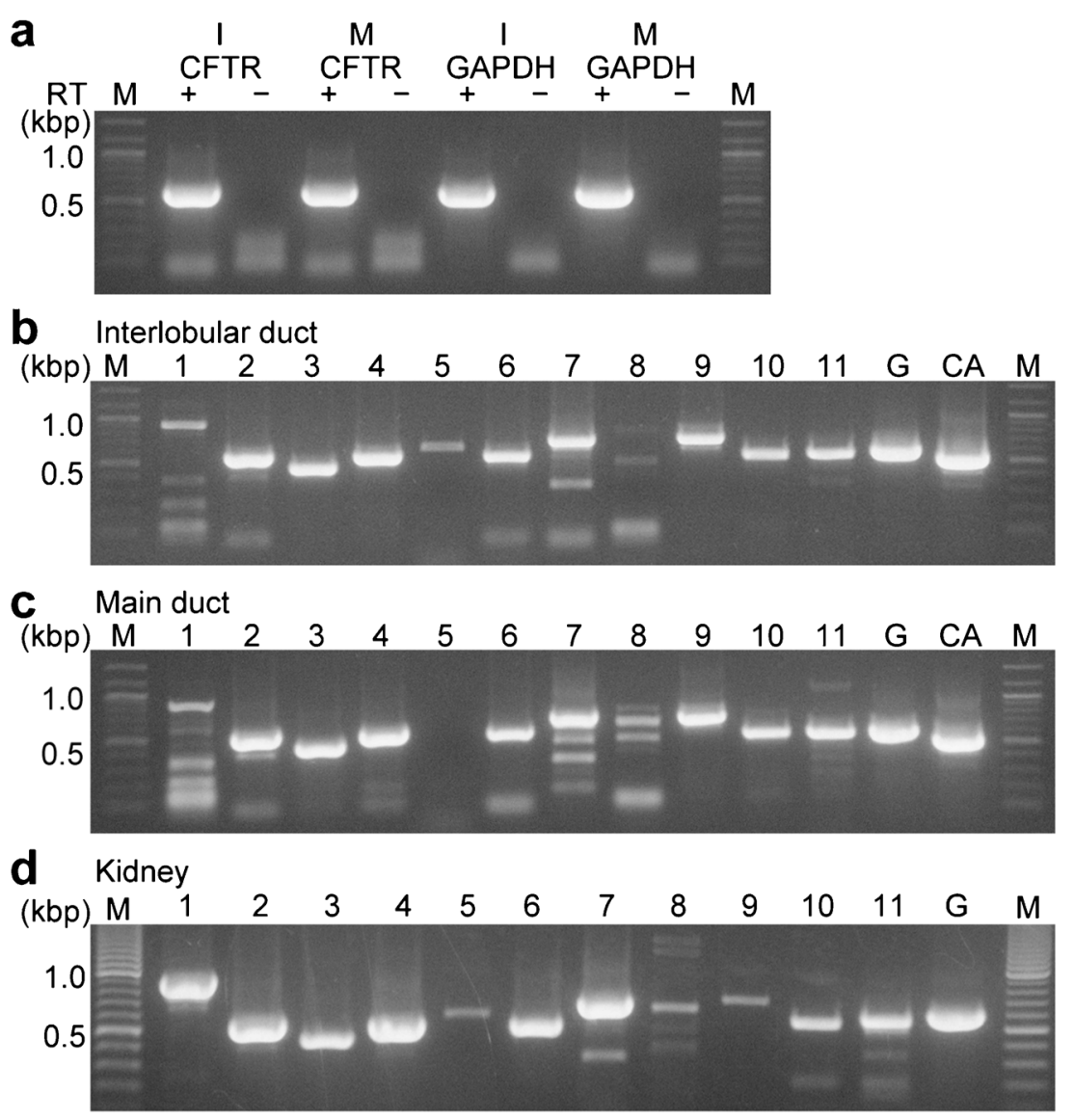

\section{Immunolocalization of the SLC26A family in pancreatic duct cells}

The immunolocalization of the SLC26A family was examined with paraffin sections of guinea pig pancreas. Immunofluorescence ascribed to the SLC26A exchanger was colocalized with Ezrin, an A-kinase anchoring protein, to the luminal membrane of the pancreatic duct (Fig. 7). In the guinea pig pancreas, immunofluorescence of SLC26A6 was detected on the luminal membranes of duct cells (Fig. 7a), as reported for the rat pancreas previously [20]. SLC26A6 were colocalized with Ezrin to the luminal membranes (Fig. 7b, c). The immunofluorescence on the luminal membranes was diminished with SLC26A6 antibody, which was pre-absorbed with the corresponding antigen for the negative control (Fig. 7d). Additionally, a strong signal ascribed to SLC26A1 was detected and colocalized with Ezrin to the luminal membrane (Fig. 7e-g). We also detected immunofluorescence of SLC26A4 and SLC26A10 on the luminal membrane of the duct cells (Fig. 7i-k and $\mathrm{m}-\mathrm{O}$, respectively). The immunofluorescence was reduced when antibodies were pre-absorbed with the corresponding antigens (Fig. 7h, 1, p). We used HPA036055 (Atlas) as the anti-SLC26A3 antibody, but failed to immunostain SLC26A3 in the guinea pig pancreas. We stained with PECAM-1, a blood vessel marker, to distinguish between pancreatic ducts and blood vessels (Fig. 7q, r).

\section{Expression of SLC26A protein in guinea pig pancreatic ducts}

We next performed western blot analysis to examine the expression of SLC26A protein in the guinea pig pancreatic ducts. We detected SLC26A6 ( 107 kDa), SLC26A1 ( $78 \mathrm{kDa})$, SLC26A4 ( 136 kDa), and SLC26A10 ( $108 \mathrm{kDa}$ ) in the lysates of the isolated ducts (Fig. 8; $n=3$ animals). The molecular mass values corresponded to those of human SLC26A proteins ( $100 \mathrm{kDa})$, which were $N$-glycosylated, expressed in HEK-293 cells [22].

\section{Discussion}

In the present study, we applied patch electrodes on the luminal membrane of guinea pig pancreatic duct cells and recorded macroscopic currents in the inside-out configuration. The inward conductance was dependent on the intracellular $\mathrm{HCO}_{3}{ }^{-}$ concentration (Fig. 1) and was reduced when intracellular $\mathrm{HCO}_{3}{ }^{-}$was replaced with $\mathrm{Cl}^{-}$, glc ${ }^{-}$, or $\mathrm{MES}^{-}$(Fig. 2) or extracellular $\mathrm{Cl}^{-}$was replaced with glc ${ }^{-}$(Fig. 3). Furthermore, the inward conductance was decreased in the presence of $\mathrm{H}_{2} \mathrm{DIDS}$, an inhibitor of $\mathrm{Cl}^{-}-\mathrm{HCO}_{3}{ }^{-}$exchangers (Fig. 4). These electrophysiological findings suggested that 
Fig. 7 Immunolocalization of the SLC26A family in the

interlobular pancreatic duct. a Fluorescence of SLC26A6 on the luminal membranes of duct cells. b Fluorescence image of ezrin. c Overlay image of $\mathbf{a}$ and $\mathbf{b}$. $\mathbf{d}$

Overlay image of ezrin and green fluorescence with SLC26A6 antibody pre-absorbed with the corresponding antigen. The broken line indicates a duct. Arrowhead indicates the primary antibody signal on the luminal membrane. Fluorescence images of SLC26A1 (e), ezrin (f), overlay (g), and negative control with preabsorbed SLC26A1 antibody (h). Fluorescence image of SLC26A4 (i), ezrin (j), overlay (k), and negative control with preabsorbed SLC26A4 antibody (I). Fluorescence images of

SLC26A10 (m), ezrin (n), overlay (o), and negative control with pre-absorbed SLC26A10 antibody (p). Fluorescence images of PECAM-1 (q), a blood vessel marker, and overlay with ezrin (r). Arrowheads show a blood vessel that does not overlap with the duct. s Control image of the guinea pig pancreas, in which primary antibodies were omitted. DAPI was used to stain nuclei (blue). Representative images for at least three independent experiments are shown. Bars $=$ $20 \mu \mathrm{m}$
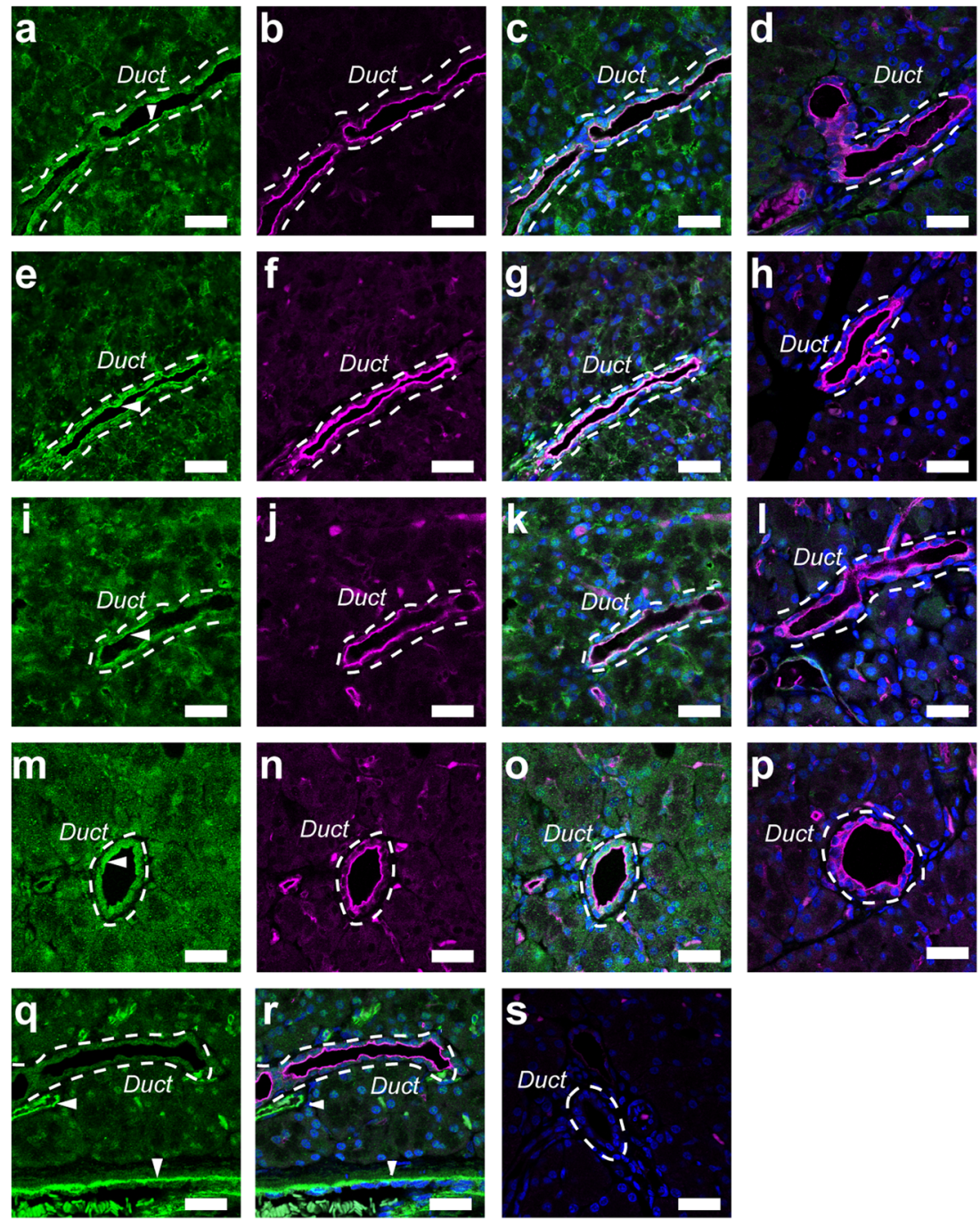

the inward conductance was ascribed to $\mathrm{HCO}_{3}{ }^{-}$efflux through $\mathrm{Cl}^{-}-\mathrm{HCO}_{3}{ }^{-}$exchangers on the luminal membrane. In addition, we found that SLC26A1, SLC26A4, SLC26A6, and SLC26A10 were localized to the luminal membrane of the pancreatic duct cells (Figs. 7 and 8).

$\mathrm{HCO}_{3}{ }^{-}$can flow outwardly not only through $\mathrm{Cl}^{-}-\mathrm{HCO}_{3}{ }^{-}$ exchangers but also through CFTR $\mathrm{Cl}^{-}$channels on the luminal membrane [7]. The permeability ratio sequence of the $\mathrm{Cl}^{-}$ channel in inside-out patches from the rat pancreatic duct cells was $\mathrm{NO}_{3}{ }^{-}>\mathrm{Cl}^{-}>\mathrm{HCO}_{3}{ }^{-}>$gluconate [7], and that in wholecell patches from the guinea pig pancreatic duct cells was $\mathrm{Br}^{-}>\mathrm{I}^{-}=\mathrm{Cl}^{-}>\mathrm{HCO}_{3}{ }^{-}>\mathrm{ClO}_{4}{ }^{-}>$aspartate [29]. These were different from the permeability ratio sequence of the inward conductance obtained in the present study: $\mathrm{SCN}^{-}>\mathrm{Cl}^{-}=$gluconate $=\mathrm{I}^{-}=\mathrm{HCO}_{3}{ }^{-}>\mathrm{MES}^{-}$(Fig. 2). Similarly, a previous study reported that the anion selectivity of SLC26A6 in
Fig. 8 Immunoblot of the

SLC26A family from the pancreatic duct. Protein samples were resolved by SDS-PAGE. Arrowheads indicate SLC26A proteins detected by immunoblotting using antiSLC26A antibodies.

Representative membranes for at least three independent experiments are shown. M, marker; A6, SLC26A6; A1, SLC26A1; A4, SLC26A4; A10, SLC26A10
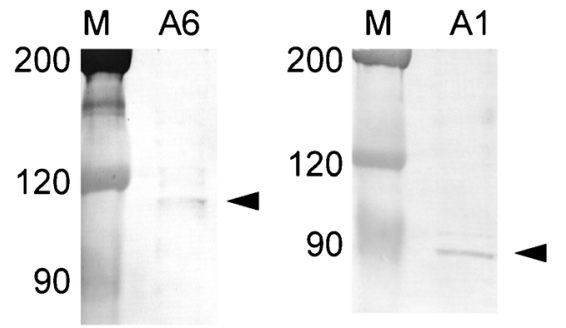

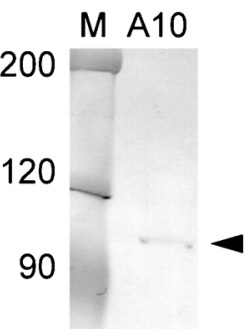




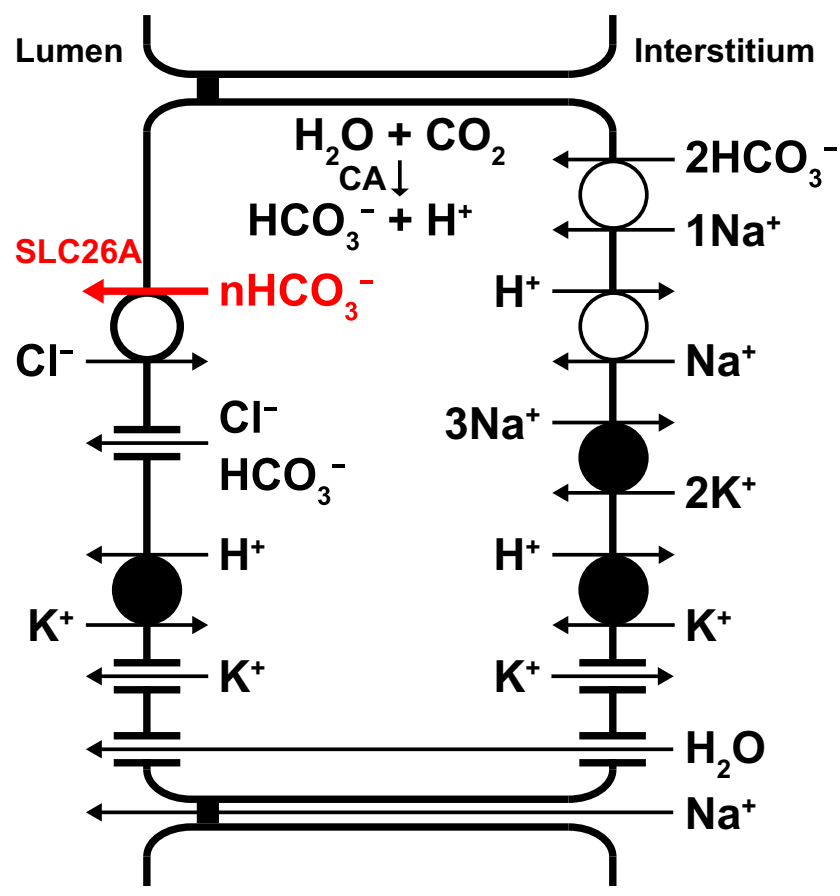

Fig. 9 Model of $\mathrm{HCO}_{3}{ }^{-}$transport in a pancreatic duct cell. Intracellular $\mathrm{HCO}_{3}{ }^{-}$is derived from $\mathrm{CO}_{2}$ through the action of carbonic anhydrase (CA) and from $\mathrm{HCO}_{3}{ }^{-}$uptake via the $\mathrm{Na}^{+}-\mathrm{HCO}_{3}{ }^{-}$cotransporter. $\mathrm{H}^{+}$is extruded at the basolateral membrane by the $\mathrm{Na}^{+}-\mathrm{H}^{+}$exchanger and $\mathrm{H}^{+}-$ $\mathrm{K}^{+}$pump. $\mathrm{HCO}_{3}{ }^{-}$efflux across the luminal membrane is mediated by $\mathrm{Cl}^{-}$ channels (CFTR and TMEM16A/ANO1) and electrogenic $\mathrm{Cl}^{-}-\mathrm{nHCO}_{3}{ }^{-}$ exchangers (SLC26A1, 4, 6, and/or 10; $n>1$ ). $\mathrm{K}^{+}$channels provide an exit pathway for $\mathrm{K}^{+}$and play a vital role in maintaining the membrane potential, which is a crucial component of the driving force for anion secretion. Luminal $\mathrm{H}^{+}-\mathrm{K}^{+}$pumps may provide a buffering/protection zone for the alkali-secreting epithelium. Primary active transport is indicated by filled circles

HEK 293 cells was $\mathrm{SCN}^{-}>\mathrm{NO}_{3}{ }^{-}>\mathrm{Cl}^{-}$[30]. Single-channel and whole-cell conductance through $\mathrm{Cl}^{-}$channels was reduced in the presence of $\mathrm{HCO}_{3}{ }^{-}[7,29]$, whereas the inward conductance was increased with increasing intracellular $\mathrm{HCO}_{3}{ }^{-}$in our experiments (Fig. 1). These results suggest that $\mathrm{HCO}_{3}{ }^{-}$efflux occurs by pathway independent from the $\mathrm{Cl}^{-}$channels. We followed previous studies that evaluated the activities of $\mathrm{Cl}^{-}-\mathrm{HCO}_{3}{ }^{-}$exchangers on the apical membrane of pancreatic ducts by replacing extracellular $\mathrm{Cl}^{-}$ with gluconate [14, 16, 43], and observed that the reversal potential shifted to a negative direction and the inward $\mathrm{HCO}_{3}{ }^{-}$conductance decreased (Fig. 3). The dependency of inward $\mathrm{HCO}_{3}{ }^{-}$conductance on extracellular $\mathrm{Cl}^{-}$suggests that $\mathrm{HCO}_{3}{ }^{-}$is exchanged for $\mathrm{Cl}^{-}$. Our results demonstrated that intracellular $\mathrm{HCO}_{3}{ }^{-}$increased the conductance with a $\mathrm{K}_{\mathrm{d}}$ value of approximately $30 \mathrm{mM}$ (Fig. 1), corresponding to the physiological concentration of intracellular $\mathrm{HCO}_{3}{ }^{-}$in duct cells. Additionally, the Hill coefficient, which was estimated to be 3.5 for the effects of $\mathrm{HCO}_{3}{ }^{-}$, suggested that positive cooperative binding of $\mathrm{HCO}_{3}{ }^{-}$facilitated the binding of subsequent $\mathrm{HCO}_{3}{ }^{-}$at other sites on $\mathrm{Cl}^{-}-\mathrm{HCO}_{3}{ }^{-}$ exchangers.
We detected SLC26A1, SLC26A4, SLC26A6, and SLC26A10 on the luminal membrane of the interlobular pancreatic duct (Fig. 7). SLC26A6 was localized to the luminal membrane of interlobular pancreatic ducts of humans [24] and rats [20], as well as to the intestine, kidney, parotid gland, and heart $[1,20,21,24,47]$. SLC26A6 cloned from guinea pig pancreatic ducts mediated $\mathrm{Cl}^{-}-\mathrm{HCO}_{3}{ }^{-}$exchange in HEK 293 cells [44]. SLC26A4 (pendrin) was localized to the apical membranes of the submandibular duct, type B and non-A, non-B intercalated cells in the cortical collecting duct of the kidney, and thyroid follicular cells, and was expressed in inner ear $[3,36,37,39]$. SLC26A4 mediates $\mathrm{HCO}_{3}{ }^{-}$secretion across the apical membrane in Calu-3, a human airway epithelia cell line, monolayers [5] and in the cortical collecting ducts [37]. SLC26A1 identified as sulfate/bicarbonate/oxalate exchangers was expressed in the liver and kidney, and to a lesser extent, in the pancreas and testis [2, 35], and detected on the basolateral membrane of kidney and liver epithelial cells $[18,34]$. SLC26A10 was found at the mRNA level in the heart and sarcoma [1, 4], but its function is unknown. Although the previous study demonstrated localization of SLC26A3 to the apical membrane of mouse pancreatic duct cells [9], we were unable to immunostain SLC26A3 in guinea pig pancreatic duct cells. The immunostaining signal in the guinea pig pancreas may be underestimated because we were only able to use antibodies against the human SLC26A family. Future studies are needed to establish the functional relevance of SLC26A molecules in pancreatic ducts.

We found that intracellular ATP and cAMP activated anion conductance on the luminal membrane in guinea pig pancreatic duct cells (Fig. 5a, b), as observed in rat pancreatic duct cells [6]. It was reported using HEK293 cells that CFTR stimulated by forskolin activated anion exchange of SLC26A3, SLC26A4, and SLC26A6 [19]. Thus, the increased conductance was attributed to activation of CFTR $\mathrm{Cl}^{-}$channels by intracellular ATP and cAMP $[6,8,29,40]$, and activation of $\mathrm{Cl}^{-}-\mathrm{HCO}_{3}{ }^{-}$exchangers by activated CFTR [19]. As anion conductance was not significantly increased in the presence of CFTRinh-172 in the pipette solution (Fig. 5c, d), we concluded that intracellular ATP and cAMP may not directly regulate $\mathrm{Cl}^{-}-\mathrm{HCO}_{3}{ }^{-}$exchangers.

We found that $\mathrm{H}_{2}$ DIDS applied intracellularly inhibited inward $\mathrm{HCO}_{3}{ }^{-}$conductance by $50 \%$ in excised inside-out patches from the luminal membrane (Fig. 4). A previous study demonstrated that other disulfonic stilbenes, 4,4'dinitrostilbene-2, $2^{\prime}$-disulphonic acid and $4,4^{\prime}$ diisothiocyanostilbene-2,2'-disulfonic acid, blocked CFTR $\mathrm{Cl}^{-}$channels when applied to the cytoplasmic face of membrane patches, with $\mathrm{K}_{\mathrm{d}}$ values (at $0 \mathrm{mV}$ ) of 160 and $80 \mu \mathrm{M}$, respectively [23]. It is likely that disulfonic stilbenes are able to act on $\mathrm{Cl}^{-}-\mathrm{HCO}_{3}{ }^{-}$exchangers from not only the outside but also from the inside of the cell membrane. 
In conclusion, we used the patch-clamp technique in the inside-out configuration and demonstrated that the $\mathrm{HCO}_{3}{ }^{-}$ conductance through the luminal membrane is mediated by $\mathrm{Cl}^{-}-\mathrm{HCO}_{3}{ }^{-}$exchangers under physiological $\mathrm{HCO}_{3}{ }^{-}$concentrations in pancreatic duct cells. Our findings suggest that SLC26A1, SLC26A4, SLC26A6, and SLC26A10 may be involved in the $\mathrm{HCO}_{3}{ }^{-}$transport through the luminal membrane. The SLC26A family may also play a role in $\mathrm{pH}$ homeostasis in the pancreatic lumen and duct cells. The direct measurement of the $\mathrm{HCO}_{3}{ }^{-}$current from the interlobular duct and its functional characterization helps to propose a useful model for $\mathrm{HCO}_{3}{ }^{-}$secretion from the pancreatic duct epithelia (Fig. 9).

Funding information This work was supported by the research grant D2 from Kansai Medical University, the Pancreas Research Foundation of Japan, and Japan Society for the Promotion of Science KAKENHI (24790226). N. Andharia was supported by the Rotary Yoneyama Memorial Foundation.

\section{Compliance with ethical standards}

Conflict of interest The authors declare that they have no conflict of interest.

Ethical approval All procedures performed in studies involving animals were in accordance with the ethical standards of the institution or practice at which the studies were conducted.

Open Access This article is distributed under the terms of the Creative Commons Attribution 4.0 International License (http:// creativecommons.org/licenses/by/4.0/), which permits unrestricted use, distribution, and reproduction in any medium, provided you give appropriate credit to the original author(s) and the source, provide a link to the Creative Commons license, and indicate if changes were made.

\section{References}

1. Alvarez BV, Kieller DM, Quon AL, Markovich D, Casey JR (2004) Slc26a6: a cardiac chloride-hyroxyl exchanger and predominant chloride-bicarbonate exchanger of the mouse heart. J Physiol 561(3):721-734. https://doi.org/10.1113/jphysiol.2004.077339

2. Bissig M, Hagenbuch B, Stieger B, Koller T, Meier PJ (1994) Functional expression cloning of the canalicular sulfate transport system of rat hepatocytes. J Biol Chem 269(4):3017-3021

3. Everett LA, Morsli H, Wu DK, Green ED (1999) Expression pattern of the mouse ortholog of the pendred's syndrome gene $(P d s)$ suggests a key role for pendrin in the inner ear. Proc Natl Acad Sci U S A 96(17):9727-9732. https://doi.org/10.1073/pnas.96.17.9727

4. Francis P, Namløs HM, Müller C, Edén P, Fernebro J, Berner JM, Bjerkehagen B, Åkerman M, Bendahl PO, Isinger A, Rydholm A, Myklebost O, Nilbert M (2007) Diagnostic and prognostic gene expression signatures in 177 soft tissue sarcomas: hypoxiainduced transcription profile signifies metastatic potential. BMC Genomics 8(1):73. https://doi.org/10.1186/1471-2164-8-73

5. Garnett JP, Hickman E, Burrows R, Hegyi P, Tiszlavicz L, Cuthbert AW, Fong P, Gray MA (2011) Novel role for pendrin in orchestrating bicarbonate secretion in cystic fibrosis transmembrane conductance regulator (CFTR)-expressing airway serous cells. J Biol Chem 286(47):41069-41082. https://doi.org/10.1074/jbc. M111.266734

6. Gray MA, Greenwell JR, Argent BE (1988) Secretin-regulated chloride channel on the apical plasma membrane of pancreatic duct cells. J Membr Biol 105(2):131-142. https://doi.org/10.1007/ BF02009166

7. Gray MA, Pollard CE, Harris A, Coleman L, Greenwell JR, Argent BE (1990) Anion selectivity and block of the small-conductance chloride channel on pancreatic duct cells. Am J Physiol 259(5): C752-C761. https://doi.org/10.1152/ajpcell.1990.259.5.C752

8. Gray MA, Plant S, Argent BE (1993) cAMP-regulated whole cell chloride currents in pancreatic duct cells. Am J Physiol 264(3): C591-C602. https://doi.org/10.1152/ajpcell.1993.264.3.C591

9. Greeley T, Shumaker H, Wang Z, Schweinfest CW, Soleimani M (2001) Downregulated in adenoma and putative anion transporter are regulated by CFTR in cultured pancreatic duct cells. Am J Physiol Gastrointest Liver Physiol 281(5):G1301-G1308. https:// doi.org/10.1152/ajpgi.2001.281.5.G1301

10. Hayashi M, Novak I (2013) Molecular basis of potassium channels in pancreatic duct epithelial cells. Channels (Austin) 7(6):432-441. https://doi.org/10.4161/chan.26100

11. Hayashi M, Wang J, Hede SE, Nova I (2012) An intermediateconductance $\mathrm{Ca}^{2+}$-activated $\mathrm{K}^{+}$channel is important for secretion in pancreatic duct cells. Am J Physiol Cell Physiol 303(2):C151C159. https://doi.org/10.1152/ajpcell.00089.2012

12. Hayashi M, Inagaki A, Novak I, Matsuda H (2016) The adenosine $\mathrm{A}_{2 \mathrm{~B}}$ receptor is involved in anion secretion in human pancreatic duct Capan-1 epithelial cells. Pflügers Arch 468(7):1171-1181. https://doi.org/10.1007/s00424-016-1806-9

13. Hille B (2001) Ionic channels of excitable membranes, 3rd edn. Sinauer Associates, Sunderland

14. Ishiguro H, Naruse S, Steward MC, Kitagawa M, Ko SB, Hayakawa T, Case RM (1998) Fluid secretion in interlobular ducts isolated from guinea-pig pancreas. J Physiol 511(2):407-422. https://doi.org/10.1111/j.1469-7793.1998.407bh.x

15. Ishiguro H, Naruse $\mathrm{S}$, Kitagawa $\mathrm{M}$, Mabuchi $\mathrm{T}$, Kondo $\mathrm{T}$, Hayakawa T, Case RM, Steward MC (2002) Chloride transport in microperfused interlobular ducts isolated from guinea-pig pancreas. J Physiol 539(1):175-189. https://doi.org/10.1113/jphysiol. 2001.012490

16. Ishiguro H, Namkung W, Yamamoto A, Wang Z, Worrell RT, Xu J, Lee MG, Soleimani M (2007) Effect of Slc26a6 deletion on apical $\mathrm{Cl}^{-} / \mathrm{HCO}_{3}{ }^{-}$exchanger activity and cAMP-stimulated bicarbonate secretion in pancreatic duct. Am J Physiol Gastrointest Liver Physiol 292(1):G447-G455. https://doi.org/10.1152/ajpgi.00286. 2006

17. Ishiguro H, Steward MC, Naruse S, Ko SB, Goto H, Case RM, Kondo T, Yamamoto A (2009) CFTR functions as a bicarbonate channel in pancreatic duct cells. J Gen Physiol 133(3):315-326. https://doi.org/10.1085/jgp.200810122

18. Karniski LP, Lötscher M, Fucentese M, Hilfiker H, Biber J, Murer H (1998) Immunolocalization of sat-1 sulfate/oxalate/bicarbonate anion exchanger in the rat kidney. Am J Physiol 275(1):F79-F87

19. Ko SB, Shcheynikov N, Choi JY, Luo X, Ishibashi K, Thomas PJ, Kim JY, Kim KH, Lee MG, Naruse S, Muallem S (2002) A molecular mechanism for aberrant CFTR-dependent $\mathrm{HCO}_{3}{ }^{-}$transport in cystic fibrosis. EMBO J 21(21):5662-5672. https://doi.org/10. 1093/emboj/cdf580

20. Ko SB, Zeng W, Dorwart MR, Luo X, Kim KH, Millen L, Goto H, Naruse S, Soyombo A, Thomas PJ, Muallem S (2004) Gating of CFTR by the STAS domain of SLC26 transporters. Nat Cell Biol 6(4):343-350. https://doi.org/10.1038/ncb1115

21. Kujala M, Tienari J, Lohi H, Elomaa O, Sariola H, Lehtonen E, Kere J (2005) SLC26A6 and SLC26A7 anion exchangers have a 
distinct distribution in human kidney. Nephron Exp Nephrol 101(2):e50-e58. https://doi.org/10.1159/000086345

22. Li J, Xia F, Reithmeier RA (2014) $N$-glycosylation and topology of the human SLC26 family of anion transport membrane proteins. Am J Physiol Cell Physiol 306(10):C943-C960. https://doi.org/ 10.1152/ajpcell.00030.2014

23. Linsdell P, Hanrahan JW (1996) Disulphonic stilbene block of cystic fibrosis transmembrane conductance regulator $\mathrm{Cl}^{-}$channels expressed in a mammalian cell line and its regulation by a critical pore residue. J Physiol 496(3):687-693. https://doi.org/10.1113/ jphysiol.1996.sp021719

24. Lohi H, Kujala M, Kerkel E, Saarialho-Kere U, Kestil M, Kere J (2000) Mapping of five new putative anion transporter genes in human and characterization of SLC26A6, a candidate gene for pancreatic anion exchanger. Genomics 70(1):102-112. https://doi.org/ 10.1006/geno.2000.6355

25. Melvin JE, Park K, Richardson L, Schultheis PJ, Shull GE (1999) Mouse down-regulated in adenoma (DRA) is an intestinal $\mathrm{Cl}^{-}$ $/ \mathrm{HCO}_{3}{ }^{-}$exchanger and is up-regulated in colon of mice lacking the NHE3 $\mathrm{Na}^{+} / \mathrm{H}^{+}$exchanger. J Biol Chem 274(32):2285522861. https://doi.org/10.1074/jbc.274.32.22855

26. Mount DB, Romero MF (2004) The SLC26 gene family of multifunctional anion exchangers. Pflügers Arch 447(5):710-721. https://doi.org/10.1007/s00424-003-1090-3

27. Novak I, Greger R (1988) Properties of the luminal membrane of isolated perfused rat pancreatic ducts. Effect of cyclic AMP and blockers of chloride transport. Pflügers Arch 411(5):546-553. https://doi.org/10.1007/BF00582376

28. Novak I, Wang J, Henriksen KL, Haanes KA, Krabbe S, Nitschke R, Hede SE (2011) Pancreatic bicarbonate secretion involves two proton pumps. J Biol Chem 286(1):280-289. https://doi.org/10. 1074/jbc.M110.136382

29. O'Reilly CM, Winpenny JP, Argent BE, Gray MA (2000) Cystic fibrosis transmembrane conductance regulator currents in guinea pig pancreatic duct cells: inhibition by bicarbonate ions. Gastroenterology 118(6):1187-1196. https://doi.org/10.1016/ S0016-5085(00)70372-6

30. Ohana E, Shcheynikov N, Yang D, So I, Muallem S (2011) Determinants of coupled transport and uncoupled current by the electrogenic SLC26 transporters. J Gen Physiol 137(2):239-251. https://doi.org/10.1085/jgp.201010531

31. Park HW, Nam JH, Kim JY, Namkung W, Yoon JS, Lee JS, Kim KS, Venglovecz V, Gray MA, Kim KH, Lee MG (2010) Dynamic regulation of CFTR bicarbonate permeability by $\left[\mathrm{Cl}^{-}\right]_{\mathrm{i}}$ and its role in pancreatic bicarbonate secretion. Gastroenterology 139(2):620 631. https://doi.org/10.1053/j.gastro.2010.04.004

32. Petersen OH, Ueda N (1977) Secretion of fluid and amylase in the perfused rat pancreas. J Physiol 264(3):819-835. https://doi.org/10. 1113/jphysiol.1977.sp011696

33. Petersen $\mathrm{OH}$, Courjaret $\mathrm{R}$, Machaca $\mathrm{K}$ (2017) $\mathrm{Ca}^{2+}$ tunnelling through the ER lumen as a mechanism for delivering $\mathrm{Ca}^{2+}$ entering via store-operated $\mathrm{Ca}^{2+}$ channels to specific target sites. J Physiol 595(10):2999-3014. https://doi.org/10.1113/JP272772

34. Quondamatteo F, Krick W, Hagos Y, Kruger MH, Neubauer-saile K, Herken R, Ramadori G, Burckhardt G, Burckhardt BC (2006) Localization of the sulfate/anion exchanger in the rat liver. Am J Physiol Gastrointest Liver Physiol 290(5):G1075-G1081. https:// doi.org/10.1152/ajpgi.00492.2005

35. Regeer RR, Lee A, Markovich D (2003) Characterization of the human sulfate anion transporter (hsat-1) protein and gene (SAT1; SLC26A1). DNA Cell Biol 22(2):107-117. https://doi.org/10. 1089/104454903321515913

36. Royaux IE, Suzuki K, Mori A, Katoh R, Everett LA, Kohn LD, Green ED (2000) Pendrin, the protein encoded by the pendred syndrome gene $(P D S)$, is an apical porter of iodide in the thyroid and is regulated by thyroglobulin in FRTL-5 cells. Endocrinology 141(2):839-845. https://doi.org/10.1210/endo.141.2.7303

37. Royaux IE, Wall SM, Karniski LP, Everett LA, Suzuki K, Knepper MA, Green ED (2001) Pendrin, encoded by the pendred syndrome gene, resides in the apical region of renal intercalated cells and mediates bicarbonate secretion. Proc Natl Acad Sci U S A 98(7): 4221-4226. https://doi.org/10.1073/pnas.071516798

38. Shcheynikov N, Wang Y, Park M, Ko SB, Dorwart M, Naruse S, Thomas PJ, Muallem S (2006) Coupling modes and stoichiometry of $\mathrm{Cl}^{-} / \mathrm{HCO}_{3}{ }^{-}$exchange by slc26a3 and slc26a6. J Gen Physiol 127(5):511-524. https://doi.org/10.1085/jgp.200509392

39. Shcheynikov N, Yang D, Wang Y, Zeng W, Karniski LP, So I, Wall SM, Muallem S (2008) The Slc26a4 transporter functions as an electroneutral $\mathrm{Cl}^{-} / \mathrm{I}^{-} / \mathrm{HCO}_{3}{ }^{-}$exchanger: role of Slc26a4 and Slc26a6 in $\mathrm{I}^{-}$and $\mathrm{HCO}_{3}{ }^{-}$secretion and in regulation of CFTR in the parotid duct. J Physiol 586(16):3813-3824. https://doi.org/10. 1113/jphysiol.2008.154468

40. Sheppard DN, Welsh MJ (1999) Structure and function of the CFTR chloride channel. Physiol Rev 79(1):S23-S45. https://doi. org/10.1152/physrev.1999.79.1.S23

41. Song Y, Yamamoto A, Steward MC, Ko SB, Stewart AK, Soleimani M, Liu BC, Kondo T, Jin CX, Ishiguro H (2012) Deletion of Slc26a6 alters the stoichiometry of apical $\mathrm{Cl}^{-} / \mathrm{HCO}_{3}{ }^{-}$ exchange in mouse pancreatic duct. Am J Physiol Cell Physiol 303(8):C815-C824. https://doi.org/10.1152/ajpcell.00151.2012

42. Steward MC, Ishiguro H, Case RM (2005) Mechanisms of bicarbonate secretion in the pancreatic duct. Annu Rev Physiol 67(1): 377-409. https://doi.org/10.1146/annurev.physiol.67.031103. 153247

43. Stewart AK, Yamamoto A, Nakakuki M, Kondo T, Alper SL, Ishiguro $\mathrm{H}$ (2009) Functional coupling of apical $\mathrm{Cl}^{-} / \mathrm{HCO}_{3}{ }^{-} \mathrm{ex}-$ change with CFTR in stimulated $\mathrm{HCO}_{3}^{-}$secretion by guinea pig interlobular pancreatic duct. Am J Physiol Gastrointest Liver Physiol 296(6):G1307-G1317. https://doi.org/10.1152/ajpgi. 90697.2008

44. Stewart AK, Shmukler BE, Vandorpe DH, Reimold F, Heneghan JF, Nakakuki M, Akhavein A, Ko S, Ishiguro H, Alper SL (2011) SLC26 anion exchangers of guinea pig pancreatic duct: molecular cloning and functional characterization. Am J Physiol Cell Physiol 301(2):C289-C303. https://doi.org/10.1152/ajpcell.00089.2011

45. Venglovecz V, Hegyi P, Rakonczay Z Jr, Tiszlavicz L, Nardi A, Grunnet M, Gray MA (2011) Pathophysiological relevance of apical large conductance $\mathrm{Ca}^{2+}$-activated potassium channels in pancreatic duct epithelial cells. Gut 60(3):361-369. https://doi.org/10. 1136/gut.2010.214213

46. Waldegger S, Moschen I, Ramirez A, Smith RJ, Ayadi H, Lang F, Kubisch C (2001) Cloning and characterization of SLC26A6, a novel member of the solute carrier 26 gene family. Genomics 72(1):43-50. https://doi.org/10.1006/geno.2000.6445

47. Wang Z, Petrovic S, Mann E, Soleimani M (2002) Identification of an apical $\mathrm{Cl}^{-} / \mathrm{HCO}_{3}{ }^{-}$exchanger in the small intestine. Am J Physiol Gastrointest Liver Physiol 282(3):G573-G579. https://doi.org/10. 1152/ajpgi.00338.2001

48. Wang Y, Soyombo AA, Shcheynikov N, Zeng W, Dorwart M, Marino CR, Thomas PJ, Muallem S (2006) Slc26a6 regulates CFTR activity in vivo to determine pancreatic duct $\mathrm{HCO}_{3}{ }^{-}$secretion: relevance to cystic fibrosis. EMBO J 25(21):5049-5057. https://doi.org/10.1038/sj.emboj.7601387

49. Wilschanski M, Novak I (2013) The cystic fibrosis of exocrine pancreas. Cold Spring Harb Perspect Med 3(5):a009746. https:// doi.org/10.1101/cshperspect.a009746

50. Yamaguchi M, Steward MC, Smallbone K, Sohma Y, Yamamoto A, Ko SB, Kondo T, Ishiguro H (2017) Bicarbonate-rich fluid secretion predicted by a computational model of guinea-pig pancreatic duct epithelium. J Physiol 595(6):1947-1972. https://doi.org/ 10.1113/JP273306 